\title{
KRITERIA PEMANDUAN BAKAT LIGA KOMPAS GRAMEDIA.
}

\author{
Dwi Setyanto \\ Hadi Rahmaddani dan Hendro Wardoyo
}

\begin{abstract}
Abstrak. Penelitian ini bertujuan untuk mengetahui kriteria pemanduan bakat Liga Kompas Gramedia yang dilakukan oleh tim pemandu bakat sehingga terpilih pemain muda berbakat untuk berlaga di Gothia Cup. Metode penelitian yang digunakan dalam penelitian ini adalah metode deskriptif dimana peneliti menjelaskan kriteria yang digunakan tim pemandu bakat Liga Kompas Gramedia dalam melakukan pemilihan pemain untuk mewakili Indonesia pada Gothia Cup.

Berdasarkan hasil pengolahan data, kriteria penilaian untuk pemain belakang yaitu pressure, cover, support, concentration, control \& restraint, 1v1. Kriteria untuk pemain tengah yaitu distribusi bola, awareness, support, mobility, disiplin, 1v1, transisi. Kriteria untuk pemain depan yaitu improvisasi, awareness, support, mobility, penetrasi, 1v1, transisi. Kriteria untuk penjaga gawang yaitu tangkapan, diving save, skim diving, punching pada ketinggian bola atas, tengah, dan menyusur tanah, 1v1, intercept, positioning, reaksi, dan teknik melempar javelin dan bowling dan teknik tendangan volley dan ground ball, komunikasi, dan waktu bermain.
\end{abstract}

\section{Kata Kunci : Kriteria, Pemanduan Bakat, Pemain Belakang, Sepakbola}

\section{PENDAHULUAN}

Sepakbola tidak hanya selalu pada jenjang sepakbola senior, justru titik mula keberhasilan sepakbola di usia senior adalah keberhasilan program grassroot dan pada tahapan sepakbola usia muda. Pada tahapan inilah merupakan awal pembentukan dari semua aspek dan kebutuhan yang dibutuhkan untuk menjadi pesepakbola professional yang memiliki kesempatan sebagai penerus sepakbola Indonesia.

Liga Kompas Gramedia merupakan salah satu kompetisi sepakbola usia muda yang diikuti oleh Sekolah Sepakbola terbaik se-Jabodetabek (Jakarta, Bogor, Depok, Tangerang, dan Bekasi) yang bekerjasama dengan Kementrian Pendidikan dan Kebudayaan, Kompas Gramedia, dan beberapa sponsor yang mendukung secara penuh terselenggaranya acara ini seperti Agung Podomoro Land, Allianz, dan SKF yang memberikan kesempatan bagi para pemain sepakbola usia muda untuk dapat mengembangkan potensi yang dimiliki serta dapat beraktualisasi dalam mengaplikasikan apa yang sudah mereka dapatkan dari hasil latihan mereka selama ini.

Prestasi tim Indonesia muda yang cukup menjanjikan ini tentu tidak dapat dilihat dengan sebelah mata, apalagi dengan selalu meningkatnya prestasi pada tiap tahunnya. Hal yang perlu diperhatikan yaitu adalah tahap persiapan tim yang matang yang dilakukan oleh masing-masing tim dengan latihan dan bimbingan dari pelatihpelatih berpengalaman serta program yang berkesinambungan. Hal lain yang juga penting yaitu peran orangtua dalam memberikan dorongan dan motivasi yang positif kepada anak-anak mereka selama proses persiapan tersebut.

Faktor lain yang juga sangat berpengaruh yaitu proses seleksi dan pemilihan pemain yang dilakukan oleh pemandu bakat Liga Kompas Gramedia yang bisa dibilang berhasil untuk dapat mencari dan melihat potensi yang menjanjikan untuk berlaga pada tahapan yang lebih tinggi bahkan dunia.

Bukan hal yang mudah dan sembarangan untuk menjadi pertimbangan para pemandu bakat pada Liga Kompas Gramedia untuk menjatuhkan pilihan, 
mengingat perlu sebuah keahlian untuk dapat mengenali potensi pemain usia muda baik dari segi antropometri, fisik, teknik, dan ketrampilan serta kepribadian dan psikologi, sehingga perlu suatu panduan untuk pemilihan pemain berbakat bagi para talent scout. Atas dasar itulah peneliti ingin meneliti bagaimana penyusunan kriteria untuk pemanduan bakat pada Liga Kompas Gramedia.

\section{PEMANDUAN BAKAT}

Talenta atau potensi merupakan suatu yang secara umum diwariskan melalui garis keturunan. Namun potensi tidak selalu dapat terlihat pada usia dini. Akan tetapi bagi para orang yang terlatih pada bidangnya masing-masing mereka mampu melihat dan mengidentifikasi melalui beberapa tanda-tanda yang rasional dan logis atau parameter sebagai upaya prediksi untuk mengembangkan potensi tersebut agar menjadi sukses dan matang pada tahapan yang selanjutnya.

Ajax mengidentifikasi beberapa parameter untuk menilai bibit-bibit pemain muda mereka yaitu dengan akronim yang disingkat menjadi TIPS :

- Technique (teknik)

- Intelegence (kecerdasan)

- Personality (personaliti atau watak karakter)

- $\quad$ Speed (kecepatan)

Russel dan Borms dalam buku

Science and Soccer yang ditulis oleh Thomas Reilly membagi beberapa tahapan kunci dalam mengidentifikasi bakat dan potensi sebagaimana dapat dilihat dalam tahapan di bawah ini yaitu :

- Deteksi

- Identifikasi

- Seleksi

- Pengembangan

Proses penyeleksian yang melihat dari beberapa parameter tersebut diharapkan cukup mampu untuk mendapatkan potensi yang ingin dicapai dan diharapkan. Menurut sistem yang ada di Jerman, tidak semua individu yang mempunyai bakat terpilih mampu untuk diberikan latihan yang sistematik. Para pemain muda terpilih melalui berbagai spesialisasi dengan pandangan bahwa mereka mampu :

- Sehat dan terbebas dari keluhan medis.

- Mampu menerima latihan dengan beban atau porsi yang berat.

- Mempunyai psikologi yang sehat dalam menjalani latihan.

- Menjaga pencapaian akademik yang bagus.

Thomas Reilly dalam jurnalnya Jurnal of Sport and Science Talent Identification and Development in Soccer menggambarkan dalam sebuah bagan tentang melakukan prediksi tentang bakat dalam sepakbola. Ia membagi 4 faktor dalam melakukan prediksi tentang bakat dan pengembangannya dalam sepakbola yaitu (1) prediksi dari segi fisik, (2) prediksi dari segi sosiologi, (3) prediksi dari psikologi dan perseptual kognitif dan kepribadian, dan (4) prediksi fisiologi.

Banyak klub-klub sepakbola yang besar juga menggunakan parameter dalam pencarian pemain muda berbakat pada akademi sepakbola usia muda mereka. Indikator dalam pengenalan potensi tersebut jika disingkat menjadi TABS yang dapat dirinci yaitu :

\section{- $\quad$ Technical (teknik ) \\ - Attitude ( perilaku) \\ - Balance ( keseimbangan ) \\ - $\quad$ Speed (kecepatan)}

Pemanduan bakat yang baik bukanlah kegiatan dimana hanya melihat satu pertandingan dan langsung memberikan penilaian atas pemain tersebut. Mereka harus dapat melakukan pengamatan dari berbagai situasi yang terjadi baik di dalam ataupun di luar lapangan, pada saat sesi latihan, pada saat berinteraksi terhadap pelatih, interaksi terhadap teman-teman, bahkan interaksi kepada orangtua. 
Berikut adalah beberapa kriteria FIFA dalam melakukan penilaian terhadap pemain muda berbakat :

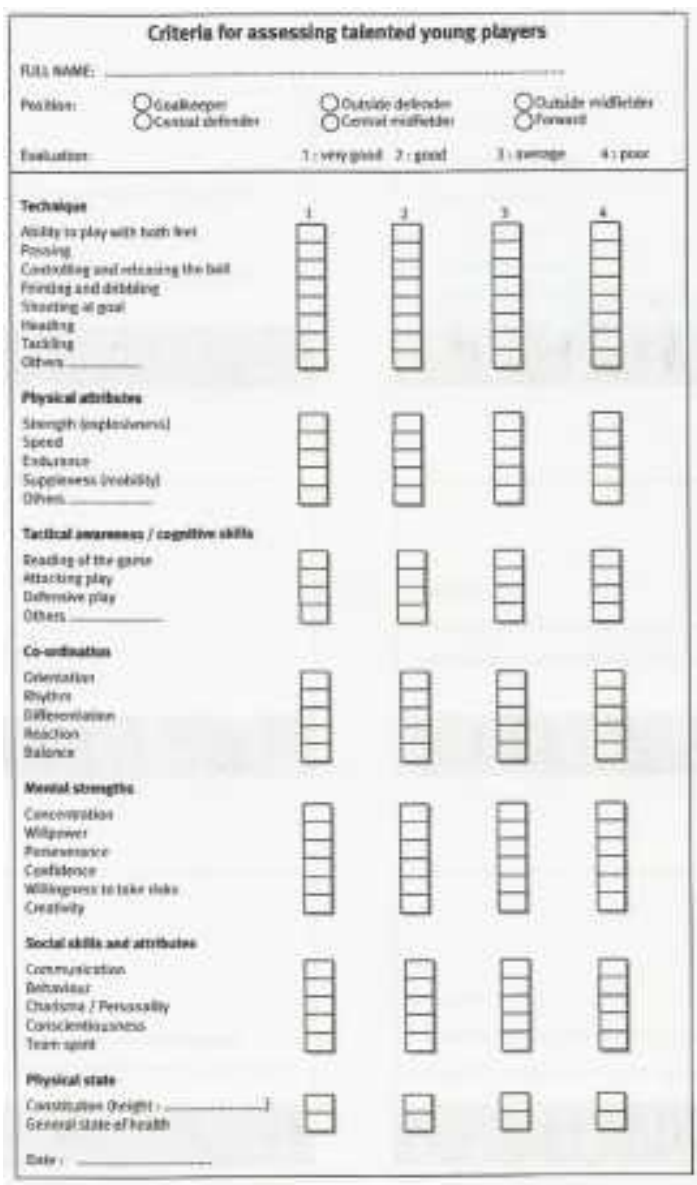

Gambar 1 : Kriteria Penilaian Pemain Muda Sumber : FIFA Player Of Tomorrow hal.21

Dari format penilaian pemain muda berbakat oleh FIFA kita dapat melihat bahwa FIFA pertama-tama membagi pemain berdasarkan posisi masing-masing. Selanjutnya terdapat kriteria penilaian dengan skala 1-4 atas 7 kriteria penilaian pemain muda berbakat yaitu teknik, kemampuan fisik, taktik, koordinasi, kondisi mental, kemampuan sosial, dan kondisi fisik.

1. Kriteria penilaian kemampuan teknik terdiri dari kemampuan bermain dengan kedua kaki, passing, control and release the ball, feinting and dribbling, shooting, heading, tackling, dan lain-lain.
2. Kriteria penilaian kemampuan fisik terdiri dari strength, speed, endurance, suppleness, dan lain-lain.

3. Kriteria penilaian terhadap taktik yaitu kemampuan dalam membaca permainan, attacking play, defensive play, dan lain-lain.

4. Kriteria penilaian terhadap koordinasi yaitu orientation, rhytim, differentiation, reaction, dan balance.

5. Kriteria penilaian kondisi mental yaitu konsentrasi, kemauan, percaya diri, keberanian dalam mengambil resiko, dan kreatifitas.

6. Kriteria penilaian kemampuan social yaitu komunikasi, perilaku, kepribadian, konsistensi, dan semangat tim.

7. kriteria dari kondisi fisik secara umum.

Hal tersebut juga dilakukan oleh tim Pemandu Bakat Liga Kompas Gramedia dalam melakukan pemilihan pemain berbakat mempunyai kriteria untuk menentukan kelayakan atas kualitas yang dimiliki pemain tersebut. Dalam proses menentukan pemain tersebut tim pemandu bakat menggunakan format penilaian pemain pada tiap posisi dengan kriteria yang berbeda-beda sesuai dengan ketrampilan yang harus dimiliki pemain tersebut.

Kriteria yang dibuat tersebut mengacu kepada Buku C License Coaching Course FIFA yang diterbitkan oleh Bidang Teknik Persatuan Sepakbola Seluruh Indonesia yang kemudian disesuaikan dengan kondisi di lapangan yang terjadi selama berlangsungnya kompetisi Liga Kompas Gramedia.

Kriteria tersebut antara lain yaitu :

Pressure adalah memberikan tekanan pada pemain yang sedang menguasai bola dengan maksud agar pemain tersebut tidak leluasa dalam menguasai bola. 
Cover adalah usaha pemain belakang untuk membantu temannya yang merupakan kelanjutan dari support dan yang harus diperhatikan adalah sudut dan jarak bola tetapi tetap mengawasi lawan yang berada disekitar bola lalu jarak pemain dengan bola dan kawan tidak terlalu jauh dan terlalu dekat agar tidak memberikan ruang diantara pemain atau di belakang pemain.

Support atau posisi bantu adalah sebuah tindakan yang dilakukan oleh pemain bertahan kedua yang terdekat dengan bola saat dikuasai lawan, mendukung pemain bertahan pertama dalam menekan lawan. Support dapat dilakukan dalam situasi menguasai bola ataupun bola dalam penguasaan lawan.

Concentration adalah sebuah tindakan yang dilakukan secara spesifik di daerah sentral pertahanan dengan cara mengumpulkan pemain bertahan di sekitar bola dengan menghubungkan dengan cover, balance, support untuk melakukannya dengan benar. Dalam hal ini pemain juga dituntut harus bisa membaca situasi kapan waktu yang tepat untuk memulihkan kondisi disaat pertandingan sedang berjalan agar konsentrasi tetap terjaga sepanjang permainan berlangsung.

Control dan restraint adalah memperhatikan situasi pertandingan sehingga dapat mengontrol dan memilih tindakan apa yang hendak diambil. Hal ini perlu dilakukan agar pemain belakang dapat mengambil keputusan yang tepat dengan memperhatikan situasi pertandingan untuk mempunyai peluang yang lebih besar untuk menang dalam perebutan bola tersebut.

Duel 1 v 1 merupakan situasi dimana duel satu lawan satu secara langsung. Dalam situasi ini biasanya pemain menyerang melakukan sebuah penetrasi atau aksi individual untuk dapat melewati pemain bertahan. Pemain bertahan berusaha untuk memenangkan duel dengan cara merebut bola atau paling tidak membuat pemain menyerang kehilangan penguasaan bola. Hal sebaliknya juga bagi pemain menyerang yang berusaha melewati pemain bertahan.

Distribusi bola merupakan suatu kemampuan yang wajib dimiliki pemain tengah untuk melakukan suplai bola baik dengan terobosan langsung ke striker atau bola daerah yang melebar ke winger. Distribusi bola yang bagus akan membuat tim dapat menguasai dan mengatur jalannya ritme pertandingan serta memperbanyak kemungkinan untuk dapat menciptakan peluang dan mencetak gol.

Awareness yaitu suatu keadaan dimana seorang pemain melihat keadaan sekitar sehingga bisa mengetahui posisi bola, teman, dan pemain lawan agar dapat mengambil keputusan tentang tindakan selanjutnya yang akan dilakukan.

Mobility atau movement merupakan suatu pergerakan yang dilakukan dengan cara berpindah posisi yang positif atau menguntungkan dengan tujuan menciptakan ruang bagi diri sendiri ataupun pemain lain sehingga memaksa pemain bertahan bergerak ke posisi yang buruk.

Transisi dari kehilangan bola menjadi menguasai bola yaitu dengan cara pemain yang berhasil melakukan intercept atau merebut bola berusaha untuk melakukan direct pass ke depan dan mengambil keuntungan dari pemain bertahan yang belum kembali ke posisi bertahan dengan tujuan mencetak gol. Maka dari itu kemampuan transisi dan kualitas passing yang memadai adalah kemampuan yang dibutuhkan untuk menjadi pemain tengah yang baik. Sebaliknya transisi juga bisa dilakukan dari menguasai bola menjadi kehilangan bola.

Improvisasi yaitu suatu kemampuan teknik untuk mengambil keputusan dengan tindakan tidak terduga yang berhubungan dengan imajinasi dan kreatifitas pemain tersebut. Seringkali dalam sebuah pertandingan terjadi perubahan situasi karena sepakbola merupakan olahraga yang dikategorikan sebagai ketrampilan terbuka yang selalu berubah-ubah. Hal itu yang dibutuhkan seorang pemain untuk 
melakukan aksi dan tindakan yang tidak terduga agar pemain bertahan lawan tidak dapat memperkirakan gerakan selanjutnya dari pemain tersebut.

Penetrasi adalah suatu kemampuan yang bisa dilakukan baik dengan atau tanpa bola dengan cara menusuk pertahanan lawan dengan cepat dan tepat. Penetrasi bertujuan untuk menciptakan situasi posisi support yang tepat baik untuk melakukan dribbling atau bisa juga untuk melakukan passing kepada teman satu tim agar dapat melakukan shooting.

\section{LIGA KOMPAS GRAMEDIA}

Liga Kompas Gramedia merupakan kompetisi anak usia 14 tahun yang

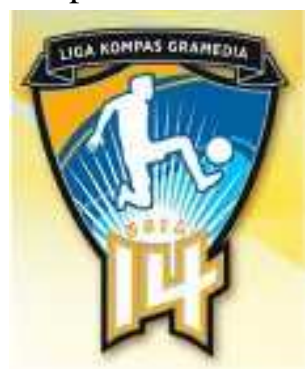
bertujuan untuk meningkatkan keterampilan pemain muda dan menjadikan pemain memiliki mental bertanding yang baik. Diikuti oleh 16 tim yang berasal dari SSB se-Jabodetabek. Kompetisi sepak bola untuk mencetak bibit-bibit muda ini berlangsung di Lapangan Gelanggang Olah Raga Ciracas Jakarta Timur. Kompetisi akan berlangsung dalam 240 pertandingan dalam sistem kompetisi penuh.

Kompetisi ini digagas oleh harian Kompas dan Warta Kota dan merangkul tim scouting talent yang berasal dari Universitas Negeri Jakarta ( UNJ ) yaitu Hadi Rahmaddani, Nursaelan S, Bambang Warsito, Irfan Permana, Dwi Hadi, dan Andri Ramawi.

Tim scouting talent mengamati dan memilih dengan berbagai pertimbangan dibantu oleh tim statistik untuk mendapatkan 66 pemain yang selanjutnya dikerucutkan menjadi 44 pemain terbaik yang melakukan adu tanding dalam laga Bintang Muda yang juga menjadi proses seleksi untuk memilih 18 pemain yang akan mewakili Indonesia pada Gothia Cup yang akan berlangsung di Gothenburg, Swedia bulan Juli mendatang.

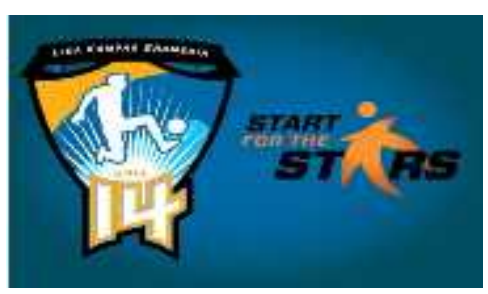

Gambar 3 : Perubahan Logo Liga Kompas Gramedia

Liga Kompas Gramedia merupakan suatu ajang kompetisi sepakbola usia 14 tahun. Kompetisi Liga Kompas Gramedia sendiri memiliki tujuan, yaitu:

1. Untuk meningkatkan keterampilan dari para pemain muda usia 14 tahun

2. Untuk menjadikan pemain yang memiliki mental bertanding yang baik.

3. Untuk mempersiapkan calon-calon pemain muda yang berbakat dalam bidang sepakbola.

Tabel 1 : Jenjang perkembangan anak usia dinimber : Pedoman Kurikulum dan Silabus

Kursus Pelatih Lisensi “D” Terjemahan

AFC Handbook Coaching Guide.Usia 13 -

TAHAP- TAHAP PERKEMBANGAN PEMAIN

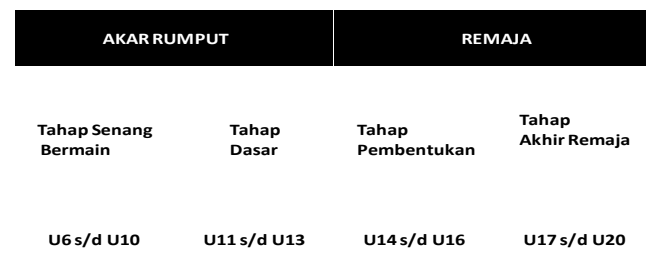

15 tahun (2006:98)

Dari tabel di atas dapat dilihat pada usia 14 tahun merupakan sebuah tahapan pembentukan untuk menjadi pemain yang matang. Perkembangan dari segi teknik, fisik, dan mental sangat penting dalam tahapan pembentukan untuk membentuk karakter pemain yang bagus baik di dalam maupun di luar lapangan. 
The Royal Netherland Football Association dalam Dutch Youth Development menerangkan bahwa untuk mengembangkan pemain usia muda perlu setidaknya 10.000 jam bermain atau sekitar 10 tahun untuk menjadi pemain sepakbola professional. Proses pengembangan pemain muda tersebut bisa dilakukan dengan cara memberi banyak kesempatan bermain, banyak sesi latihan, dan jika perlu diadakan tugas tambahan di rumah diluar jam latihan regular. Pemain tersebut membutuhkan sekitar 6 sesi latihan tiap minggunya dan setidaknya satu atau dua pertandingan di tiap minggunya.

Dutch Youth Development menulis bahwa usia 14 tahun adalah sebuah tahapan kompetisi peralihan sebelum masuk ke kompetisi sebenarnya. Pada tahap ini juga menggarisbawahi agar mereka diberikan banyaknya kesamaan waktu bermain, bahwa setiap anak mempunyai hak yang sama dalam olahraga dengan anak-anak lainnya di usia mereka dan berada pada tingkatan yang sama dengan klub dimana mereka bermain.

Tim pemandu bakat Liga Kompas Gramedia melakukan pemantauan kepada para pemain di tiap pertandingannya dan kemudian memberikan laporan yang selanjutnya didiskusikan sesama pemandu bakat untuk membicarakan tujuan dan persepsi dan pertimbangan pemilihan pemain berbakat tersebut.

\section{KERANGKA BERFIKIR}

Keterampilan sepakbola yang dimiliki seorang pemain tidak didapat secara instan, akan tetapi melalui sebuah proses panjang yang memerlukan adanya program latihan yang sistematis dan kemauan serta kerja keras pantang menyerah secara terus-menerus. Hal ini bisa dimulai pada tahap awal pembentukan usia muda yaitu pada usia 14 tahun. Pada usia 14 tahun pertumbuhan berjalan sangat baik dan merupakan waktu yang tepat untuk membangun seorang pemain sepakbola yang hebat.
Pada masa ini perkembangan multilateral berjalan kompleks dari perkembangan fisik, teknik, dan taktik, bahkan psikologi dapat menjadi penentu terhadap kualitas pemain sepakbola di masa selanjutnya.

Tidak hanya itu, disaat mereka sudah mendapatkan pelatihan yang bagus, fasilitas memadai, dukungan dari orangtua yang luar biasa tentunya mereka butuh suatu wadah kompetisi untuk memfasilitasi mereka untuk menyalurkan bakat dan potensi yang mereka miliki dimana dalam hal ini Liga Kompas Gramedia dapat memberikan itu yang mereka butuhkan sebagai tempat untuk aktualisasi diri dan sosialisasi terhadap diri dan lingkungan sepakbola.

Liga Kompas Gramedia berlangsung selama 30 pekan di setiap hari minggu yang berarti setiap tim melakukan 30 pertandingan sepanjang musim. Hal ini berbeda dengan kebanyakan kompetisi lainnya dimana pada sebuah kejuaraan hanya berlangsung satu atau dua minggu. Waktu kompetisi yang panjang ini mempunyai keuntungan dimana kekurangan dan kesalahan yang dilakukan para pemain tersebut dapat dievaluasi dan diperbaiki pada sesi latihan selama satu minggu ke depan sehingga akan selalu terjadi perbaikan dan kemajuan sepanjang musim. Proses kemajuan yang ajeg dan konsisten ini yang diharapkan untuk menjadikan para pemain muda ini tumbuh menjadi pemain yang bagus.

Keberadaan tim pemandu bakat pada Liga Kompas Gramedia mempunyai tanggung jawab yang besar terhadap pengenalan dan pengembangan bakat dan potensi pemain muda. Mereka harus benarbenar mampu melihat dan memahami gejala dan tanda-tanda baik secara fisik, teknik, taktik, dan kepribadian dari setiap pemain agar dapat memberikan prediksi tentang pemain ini di waktu yang akan datang. 
Pemain yang nantinya terpilih melalui proses penyeleksian Liga Kompas Gramedia nantinya akan mewakili Indonesia pada Gothia Cup yang diselenggarakan di Swedia. Gothia Cup merupakan ajang tahunan sepakbola yang diikuti oleh anak-anak muda dari seluruh dunia. Hal ini juga yang menjadi pertimbangan oleh tim pemandu bakat agar pemain yang terpilih dapat bersaing dengan pemain-pemain usia muda dari seluruh dunia untuk mengharumkan nama Indonesia di dunia.

Penyeleksian tersebut dapat dilihat dari segi antropometri pemain seperti tinggi dan berat badan serta ukuran postur tubuh, kondisi fisik pemain seperti daya tahan, kecepatan, kelincahan, kemampuan mengambil keputusan yang cepat dan tepat, dan visi dalam bermain sepakbola. Hal ini sangat penting melihat bahwa mereka akan bermain dalam level dunia dimana yang banyak kita tahu rata-rata orang Eropa dan Amerika memiliki keunggulan dari segi antropometri dan kemampuan fisik.

Faktor lain yang tidak kalah penting yaitu attitude atau kepribadian dari pemain itu sendiri. Pemain yang memiliki kemampuan yang lengkap dari segi fisik maupun teknik tidak berarti jika tidak dilengkapi dengan kepribadian yang bagus. Kepribadian yang bagus akan membuat kita mampu menghargai pelatih, orangtua, lawan, teman satu tim, suporter, dan semua yang terlibat dalam sepakbola baik dalam proses latihan maupun dalam pertandingan.

Kepribadian yang baik akan memudahkan jalannya proses pertukaran informasi dan timbal balik antara pemain dan pelatih ataupun sebaliknya. Disamping itu dengan memiliki kepribadian yang baik pemain akan selalu dapat mengontrol emosi baik di dalam ataupun di luar lapangan sehingga menjauhkan dari masalah baik yang berhubungan dengan pertandingan ataupun yang tidak.

Kompetisi yang terencana dengan matang dan berjenjang tentu akan menjadi hal yang sangat membantu mereka untuk mengembangkan dan sebagai pembentukan karakter yang lebih matang untuk keperluan masa datang menjadi pemain sepakbola professional yang akan menjunjung tinggi nama Indonesia di dunia persepakbolaan kelak.

\section{PENYUSUNAN KRITERIA}

Dalam melakukan penyusunan kriteria pemanduan bakat pada Liga Kompas Gramedia peneliti melakukan beberapa tahapan yaitu :

1. Studi literatur terhadap sumber-sumber referensi atau data apapun yang dibutuhkan untuk menyusun pemanduan bakat pemain muda dari berbagai sumber, diantaranya dari buku Talent Identification and Development in Soccer ( 2000, Thomas Reilly), Player Of Tomorrow ( 2010, FIFA ), buku AFC C Licence Coaching Manual ( 1997, AFC ), dan Bahan Teori Pelatihan Pelatih Lisensi C ( 2009, PSSI ).

2. Dalam buku Teori Pelatihan Pelatih Lisensi $\mathrm{C}$ yang diterbitkan oleh PSSI terdapat prinsip-prinsip bermain sepakbola baik dalam prinsip bertahan maupun menyerang. Prinsip bertahan dan menyerang tersebut adalah yang menjadi dasar bagi metode permainan untuk berbagai posisi dalam sepakbola seperti pemain bertahan, pemain tengah, maupun pemain depan, dan penjaga gawang.

3. Seorang pemain bertahan membutuhkan ketrampilan dalam delay untuk membaca situasi kapan waktu yang tepat untuk merebut bola. Hal ini dilakukan dengan maksud melihat keadaan ketika lawan sedang dalam posisi lemah atau unbalance sehingga bola dapat lebih mudah direbut untuk kemudian membalikkan keadaan.

4. Support dibutuhkan di sekitar bola untuk membantu pemain bertahan lainnya. Dalam melakukan support sebaiknya tidak terlalu jauh karena 
dapat memberikan ruang kepada lawan untuk melakukan throughpass ataupun running with the ball, dan tidak terlalu dalam karena dengan melakukan terlalu dalam itu berarti posisi lawan berada semakin dekat dengan gawang.

5. Concentration yaitu mengumpulkan pemain bertahan untuk menutup daerah gawang. Hal ini dilakukan dengan prinsip bola-pemain belakanggawang dengan tujuan menutup ruang gerak pemain dan bola secara langsung ke gawang. Dalam melakukan concentration selalu dikaitkan dengan cover dan support.

6. Seorang pemain tengah bertugas untuk memberikan suplai bola ke depan sehingga membutuhkan kemampuan dalam melakukan distribusi bola dan awareness yang baik agar dapat melihat ruang kosong yang dapat dimanfaatkan dan mobilitas untuk mengacaukan organisasi pertahanan lawan. Selain itu pemain tengah juga mampu melakukan ketrampilan bertahan karena mereka yang pertama kali melakukan pertahanan sehingga membutuhkan ketrampilan bertahan seperti support, disiplin, dan transisi yang baik.

7. Awareness dapat diartikan dengan melihat situasi sekitar dimana bola, dimana teman, dimana lawan. Dengan kemampuan awareness yang baik seorang pemain dapat bermain dengan melakukan passing kepada teman yang tidak dijaga oleh lawan, ke ruang yang kosong, ataupun bisa juga dengan melakukan dribbling sendiri melewati lawan.

8. Improvisasi dibutuhkan seorang pemain depan dalam usaha mencetak gol, ketrampilan penetrasi juga dibutuhkan untuk menusuk pertahanan lawan sehingga dapat masuk ke daerah pertahanan lawan dan lebih dekat dengan gawang untuk melakukan shooting untuk mencetak gol ataupun passing ke teman satu tim yang berpeluang lebih besar.

9. Seorang penjaga gawang membutuhkan ketrampilan untuk mengamankan gawang dari berbagai ketinggian dan reaksi dan kemampuan dalam mengambil keputusan yang cepat dan tepat. Selain itu juga mampu untuk melakukan komunikasi dengan baik karena seorang penjaga gawang yang mengingatkan dalam organisasi pertahanan untuk menjaga gawang tidak kebobolan.

10. Teknik tangkapan merupakan kemampuan yang dikuasai sebagai seorang penjaga gawang, tangkapan tersebut terdiri dari diving save atau melakukan tangkapan sambil seolaholah terbang, skim diving, dan melakukan punching atau tinju pada bola apabila bola yang bergulir susah dikendalikan.

11. Kemampuan dalam melakukan tangkapan dari berbagai variasi ketinggian juga wajib dimiliki kiper antara lain bola menyusur tanah atau ground ball, bola ketinggian sedang atau medium ball, dan bola atas atau high ball.

12. Penjaga gawang juga mempunyai peranan dalam membantu membangun serangan dari lini bertahan yang bisa dilakukan dengan lemparan ataupun tendangan langsung ke depan yang mengarah ke pemain depan.

13. Lemparan dapat dilakukan dengan melakukan lemparan seperti javelin throw dengan bola cepat yang biasanya langsung dilakukan ke arah sayap atau zona tengah permainan. Atau bisa juga dengan bowling throw yaitu bola menyusur tanah yang biasanya diarahkan ke 2 pemain belakang atau biasa disebut fullback.

14. Tendangan dapat dilakukan dengan volley ball yang ditujukan langsung ke depan yang biasanya dilakukan dalam serangan balik atau counter attack, hal ini dilakukan dengan melihat bahwa 
pemain bertahan lawan belum kembali ke posisi dan organisasi pertahanan masih kacau. Selain itu tendangan menyusur tanah atau ground ball yang biasanya dilakukan kepada fullback untuk membangun serangan dari bawah.

15. Selanjutnya peneliti melihat kondisi sebenarnya yang terjadi dalam pelaksanaan Liga Kompas Gramedia di lapangan dan kemudian membakukan kriteria yang dinilai cocok untuk digunakan dalam pemanduan pemain muda berbakat pada Liga Kompas Gramedia.

16. Dalam melakukan pemanduan bakat pada Liga Kompas Gramedia, tim pemandu bakat melakukan 5 proses tahapan pemanduan dengan tujuan yang berbeda.

a. Tahapan pertama yaitu tahap pengidentifikasian pemain. Tahapan ini berlangsung pada pekan ke-1 sampai pekan ke-7 pelaksanaan Liga Kompas Gramedia dengan tujuan mengidentifikasi bakat dari seluruh peserta Liga Kompas Gramedia sehingga mendapatkan 72 pemain yang ditandai.

b. Tahapan kedua yaitu tahap pendataan pemain yang berlangsung mulai pekan ke-8 sampai pekan ke-12. Pemain yang sudah ditandai dari tahapan pertama dipantau dan dipilih sehingga semakin mengerucut dan didapat sebanyak 44 pemain.

c. Tahapan ketiga yaitu tahap pemantapan dan penetapan pemain yang berlangsung 5 pekan sampai pekan ke-17. Sebanyak 44 pemain tersebut selanjutnya tergabung dalam tim Bintang Muda dan dibagi menjadi 4 tim yang saling berhadapan dalam laga bintang muda yang menguatkan tim pemandu bakat dalam melakukan penetapan 18 pemain yang selanjutnya akan dipilih mewakili Indonesia bertanding pada Gothia Cup 2013 di Swedia.

d. Tahapan selanjutnya yaitu tahap pemantauan yang lebih mendalam berlangsung pada pekan ke-17 sampai pekan ke-27 mengenai 18 pemain yang terpilih dengan menggunakan bantuan video yang diambil menggunakan handycam oleh tim pendukung pemandu bakat mengenai skill individual tiap pemain tersebut.

e. Tahapan terakhir yaitu tahap evaluasi dan penyusunan laporan. Pada tahapan ini tim pemandu bakat melakukan evaluasi berkaitan dengan pemilihan pemain dan menyusun laporan untuk kemudian diserahkan kepada komite Liga Kompas Gramedia

\section{HASIL KRITERIA PEMANDUAN BAKAT}

Berdasarkan pengambilan data maka dapat disimpulkan dalam melakukan pemanduan bakat pada Liga Kompas Gramedia para pemandu bakat mengidentifikasi dan memantau perkembangan para pemain berbakat dengan menggunakan kriteria tertentu yang berbeda bagi setiap posisi dalam setiap pertandingan selama 30 pekan. Kriteria tersebut didapat dari hasil penyesuaian dari beberapa sumber referensi yang dinilai cocok untuk digunakan dalam penilaian pemain berbakat Liga Kompas Gramedia.

Pemanduan bakat tersebut terbagi menjadi beberapa tahapan kegiatan dari setiap pekan yang menjadi dasar dalam pemanduan pemain berbakat pada Liga Kompas Gramedia untuk masuk ke dalam 
tim Indonesia yang akan bertanding pada kejuaraan sepakbola dunia tahunan Gothia Cup yang berlangsung di Gothenburg, Swedia.

Seperti yang telah dijelaskan pada deskripsi data diatas bahwa dalam melakukan pemanduan bakat pada Liga Kompas Gramedia untuk memilih pemain yang akan mewakili tim Indonesia pada kejuaraan sepakbola tahunan Gothia Cup yang berlangsung di Swedia, tim pemandu bakat melakukan pengamatan pada seluruh pemain tim peserta Liga Kompas Gramedia dan membagi menjadi 5 tahapan kegiatan dimana pada setiap tahapan tersebut terbagi dalam beberapa pekan yang mempunyai tujuan berbeda sebagaimana terlihat dalam tabel di bawah ini :

Tabel 2

Proses Tahapan Pemanduan Bakat Liga Kompas Gramedia

\begin{tabular}{|c|c|}
\hline Kegiatan & Pekan \\
\hline $\begin{array}{c}\text { Pengidentifikasian } \\
\text { pemain }\end{array}$ & 7 \\
\hline Pendataan pemain & 5 \\
\hline $\begin{array}{c}\text { Pemantauan dan } \\
\text { penetapan pemain }\end{array}$ & 5 \\
\hline $\begin{array}{c}\text { Pemantauan lebih } \\
\text { mendalam (video) }\end{array}$ & 10 \\
\hline Evaluasi dan laporan & 3 \\
\hline
\end{tabular}

Proses pengamatan yang dilakukan oleh tim pemandu bakat Liga Kompas Gramedia diawali dengan mengamati para pemain berbakat lewat format daftar susunan pemain dalam setiap pertandingan setiap pekannya. Melalui format daftar susunan pemain tersebut tim pemandu bakat melakukan identifikasi pemain berbakat yang berlangsung dari pekan ke-1 sampai pekan ke-7 sehingga mendapatkan 72 pemain dari total 400 pemain.

Setelah itu masuk ke tahapan kedua yaitu tahap pendataan pemain berbakat yang berlangsung selama 5 pekan sampai pekan ke-12 sehingga jumlah pemain menjadi semakin mengerucut yaitu sebanyak 44 pemain yang tersisa.

Selanjutnya 44 pemain inilah yang tergabung dalam tim Bintang Muda yang kemudian dibagi menjadi 4 pemain yang kemudian berlanjut ke tahapan selanjutnya yaitu tahap pemantapan dan penetapan pemain yang diseleksi melalui pertandingan.

Hasil dari seleksi pada pertandingan tim Bintang Muda tersebut yaitu terpilih 18 pemain yang nantinya akan berangkat mewakili tim Indonesia pada Gothia Cup di Swedia bersama dengan pelatih dari Sekolah Sepakbola ASIOP Apacinti yang menjadi Juara Paruh Musim pada Liga Kompas Gramedia 2013.

Pada putaran musim kedua tim pemandu bakat Liga Kompas Gramedia melakukan pemantauan yang lebih mendalam terhadap para pemain berbakat yang sudah terpilih melalui bantuan video individual yang diambil dengan handycam oleh tim pendukung statistik agar lebih mengenal karakteristik, tipikal, dan kelebihan serta kekurangan pemain tersebut.

Tahapan terakhir yaitu pada pekan ke-28 sampai pekan ke-30 adalah tahap evaluasi dan laporan tim pemandu bakat kepada Komite Liga Kompas Gramedia.

\section{Kriteria Pemanduan Bakat Liga Kompas Gramedia \\ Tim Pemandu Bakat Liga Kompas} Gramedia dalam melakukan pemilihan pemain berbakat mempunyai kriteria untuk menentukan kelayakan atas kualitas yang dimiliki pemain tersebut. Dalam proses menentukan pemain tersebut tim pemandu bakat menggunakan format penilaian pemain pada tiap posisi dengan kriteria yang berbeda-beda sesuai dengan ketrampilan yang harus dimiliki pemain tersebut.

Kriteria yang dibuat tersebut mengacu kepada Buku C License Coaching 
Course FIFA yang diterbitkan oleh Bidang Teknik Persatuan Sepakbola Seluruh Indonesia yang kemudian disesuaikan dengan kondisi di lapangan yang terjadi selama berlangsungnya kompetisi Liga Kompas Gramedia.

2. Kriteria Penilaian Pemain Belakang Liga Kompas Gramedia

Tabel 3

Format Penilaian Pemain Belakang Liga

Kompas Gramedia

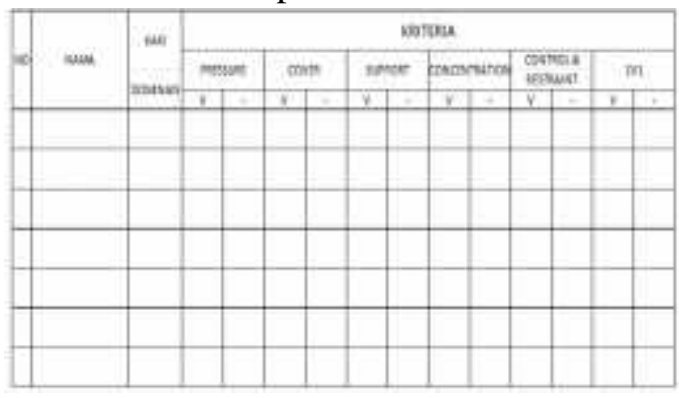

Keterangan :

(v) : Baik

( - ) : Kurang baik

3. Kriteria Penilaian Pemain Tengah Liga Kompas Gramedia

Berikut ini adalah format yang digunakan dalam penilaian pemain tengah pada Liga Kompas Gramedia :

Tabel 4

Format Penilaian Pemain Tengah Liga Kompas Gramedia

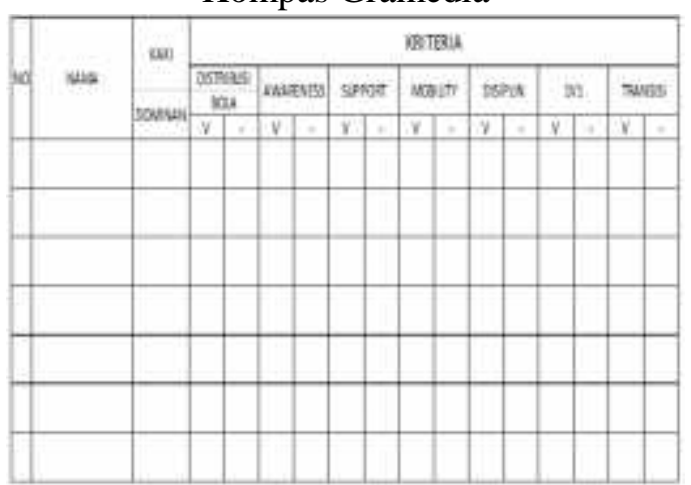

Keterangan :

( v ) : Baik

(-) : Kurang baik
4. Kriteria Penilaian Pemain Depan Liga Kompas Gramedia

Berikut ini adalah format yang digunakan dalam penilaian pemain depan pada Liga Kompas Gramedia :

Tabel 5 :

Format Penilaian Pemain Depan Liga

Kompas Gramedia

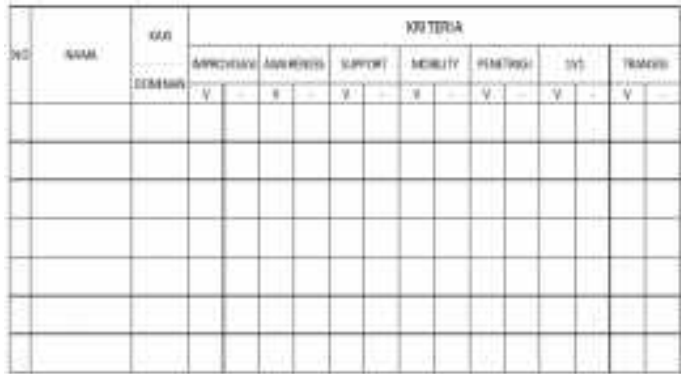

Keterangan :

( v ) : Baik

( - ) : Kurang baik

5. Kriteria Penilaian Penjaga Gawang Liga Kompas Gramedia

Berikut ini adalah format yang digunakan dalam penilaian penjaga gawang

Tabel 6

Format Penilaian Penjaga Gawang Deffense Liga Kompas Gramedia

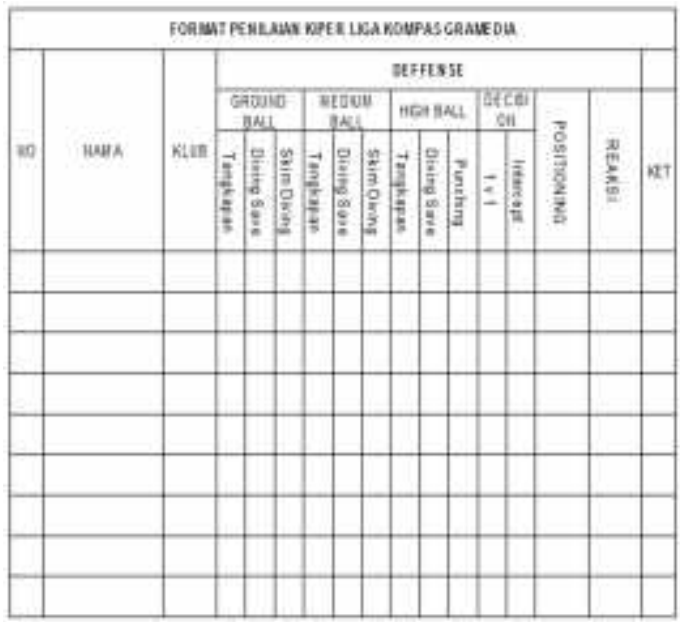


Tabel 7

Format Penilaian Kiper Offense Liga Kompas Gramedia

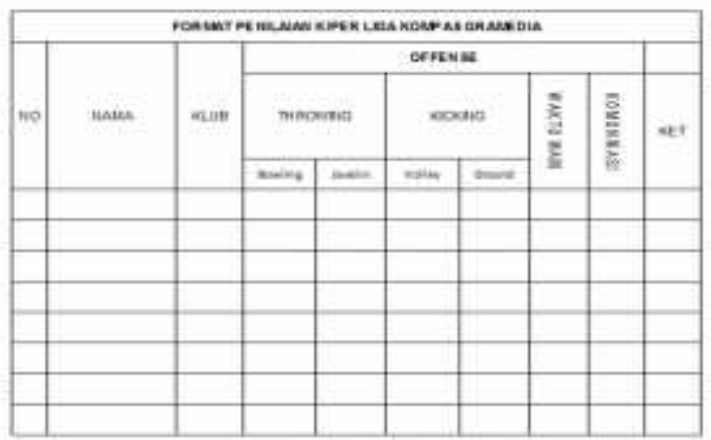

Dari kriteria yang diamati di atas tim pemandu bakat kemudian membuat peringkat. Hal lain yang juga diperhatikan yaitu keadaan emosional kiper seperti ketenangan dan attitude selama jalannya pertandingan dan postur tubuh kiper itu sendiri.

Postur yang tinggi merupakan nilai tambah bagi seorang kiper, akan tetapi yang pertama dilihat yaitu dari teknik dasarnya dulu dimana sudah dijelaskan peneliti di atas.

Berdasarkan pengamatan yang dilakukan tim pemandu bakat Liga Kompas Gramedia sepanjang berjalannya kompetisi yang melalui tahapan pemilihan yang sudah peneliti jelaskan di atas, pada akhirnya didapat 18 pemain yang telah memenuhi kriteria yang ditentukan.

Tahapan yang dilakukan selanjutnya yaitu tim pemandu bakat Liga Kompas Gramedia menyusun raport atau laporan dari 18 pemain yang akan bertanding pada kejuaraan Gothia Cup di Gothenburg, Swedia.

Berikut adalah salah satu contoh kriteria pemain tersebut ;
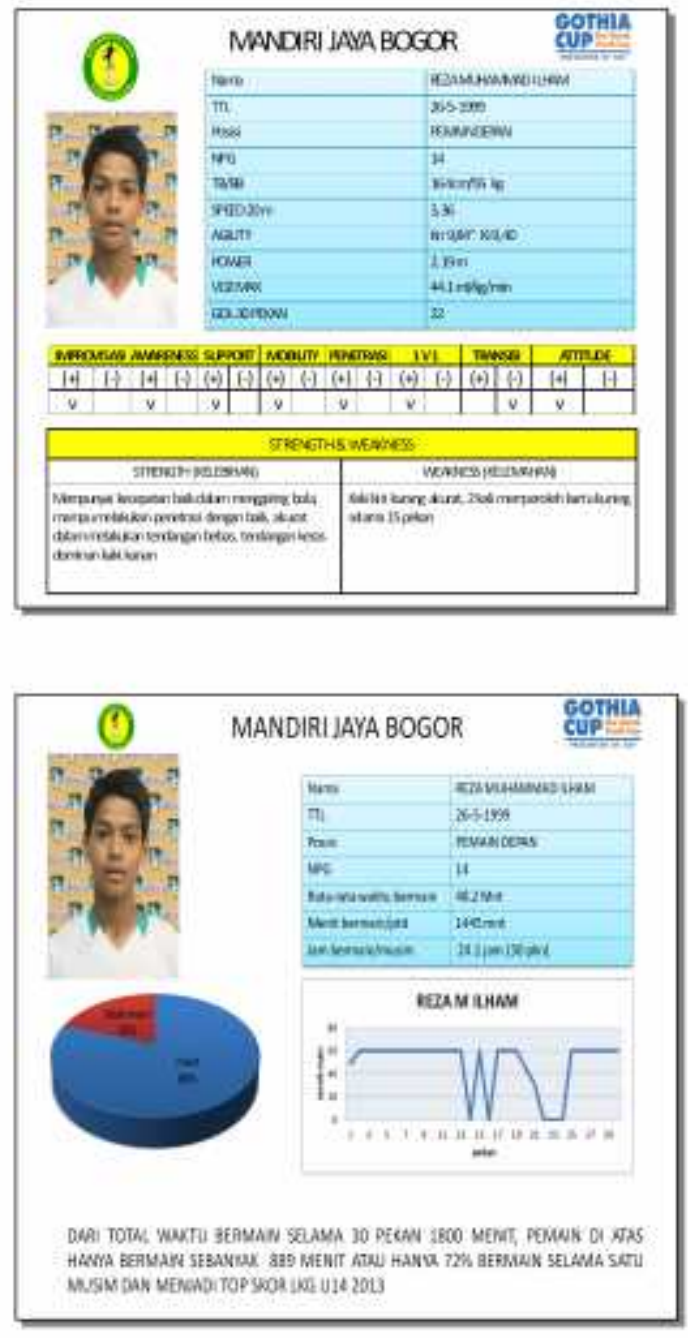

\section{KESIMPULAN}

Berdasarkan data yang diperoleh dari beberapa kriteria pemanduan bakat pemain muda dan tim pemandu bakat Liga Kompas Gramedia, maka peneliti dapat menarik kesimpulan sebagai berikut :

1. Kriteria pemilihan pemain belakang yang dilakukan tim pemandu bakat Liga Kompas Gramedia yaitu pressure, cover, support, concentration, control and restraint, dan $l v l$.

2. Kriteria pemilihan pemain tengah yang dilakukan tim pemandu bakat Liga Kompas Gramedia yaitu distribusi bola, awareness, support, mobility, disiplin, I $v 1$, dan transisi.

3. Kriteria pemilihan pemain depan yang dilakukan tim pemandu bakat Liga Kompas Gramedia yaitu improvisasi, awareness, support, mobility, penetrasi, I 1 , dan transisi. 
4. Kriteria pemilihan kiper yang dilakukan tim pemandu bakat Liga Kompas Gramedia yaitu teknik tangkapan, diving save, skim diving, dan punching pada 3 ketinggian bola yaitu ground ball, medium ball, dan high ball, ditambah decision making yang terdiri atas $1 \mathrm{v} 1$ dan intercept, positioning, reaksi, lemparan bola yang terdiri atas bowling throw dan javelin throw, menendang bola yang terdiri atas volley ball dan ground ball, waktu bermain, dan komunikasi.

\section{SARAN}

Berdasarkan kesimpulan di atas, maka peneliti mengajukan saran sebagai berikut :

1. Bagi Liga Kompas Gramedia, agar kriteria pemanduan bakat pemain muda ini dapat menjadi acuan dalam pemilihan pemain pada Kompetisi Liga Kompas Gramedia selanjutnya.

2. Bagi PSSI, kriteria ini bisa digunakan untuk melakukan seleksi pemain muda berbakat yang berkualitas berdasarkan data dan fakta yang diambil secara obyektif.

3. Bagi para pelatih, dapat melihat potensi pemain muda berbakat dengan acuan panduan ini dan kemudian meningkatkan ketrampilan para pemain sesuai dengan karakteristik posisi yang dibutuhkan.

4. Bagi para pelatih, kriteria ini dapat menjadi acuan dalam penyusunan program latihan.

5. Bagi para pemain, agar dapat memahami ketrampilan yang dibutuhkan sesuai posisi untuk menjadi pemain sepakbola yang baik.

6. Bagi para orang tua, agar dapat memahami proses pemanduan bakat pemain muda sehingga diharapkan mampu melihat kegiatan pemain semacam ini secara obyektif

7. Bagi para mahasiswa yang tertarik untuk membahas mengenai penelitian ini lebih lanjut dapat melakukan penelitian yang lebih mendalam lagi.

\section{DAFTAR PUSTAKA}

AFC. Asian Football Confederation "C" Licence Coaching Manual, 1997 “D” Licence Coaching Manual, 1994

Arie Sutopo, Buku Praktik Faal Kerja, 2006

Badudu, Kamus Umum Bahasa Indonesia, Jakarta : Sinar Harapan, 1996

Bidang Teknik, Bahan Teori Pelatihan Pelatih Lisensi C, Jakarta : PSSI, 2009

Depdikbud, Kamus Besar Bahasa Indonesia Edisi Kedua. Jakarta : Balai Pustaka, 1997

Dutch Youth Development, Talent Development In Netherland Handbook. KNVB, 2010

Mielke, Danny, Dasar-dasar Sepakbola. Pakar Raya, 2003

FIFA, The Player Of Tomorrow handbook, 2010

Reilly, Thomas, Jurnal of Sport and Science Talent Identification and Development in Soccer. John Morres University. Liverpool, 2000 , Science and Soccer Second Edition. New York: Routledge, 2003

Sukardi, Metodologi Penelitian Pendidikan Kompetensi dan Praktiknya. Yogyakarta : Bumi Aksara, 2003 